\title{
Alternatif Aplikasi Mudah Perpustakaan (Pengenalan Aplikasi ASP.Net )
}

\author{
Rosiana Nurwa Indah \\ Program Studi Ilmu Perpustakaan dan Informasi Fakultas Komunikasi, Universitas Islam \\ Nusantara \\ J1. Soekarno-Hatta No.530 Kota Bandung, Jawa Barat 40286 \\ e-mail: rosianaindah7@gmail.com
}

\begin{abstract}
Introduction. Today we enter an era where the use of technology in everyday life is very natural. The use of this technology turned out to pose a challenge for information providers, one of them was the library. The library must be able to present information that collaborates with technology so that information can be conveyed effectively and efficiently to its users. One of them is by providing library websites using ASP.Net, which is server-side technology to develop web applications based on Microsoft .NET framework. Thus, libraries can create dynamic sites and web applications that are interactive, easy to use, easy to develop.

Data Collection Method. In collecting data in this paper the writer uses data collection methods in the form of Results and Discussions. This article discusses the history of ASP. Net and its objects namely Namespace, Web Form, Basic Web Form Syntax, Class Page, Request Object, Respone Object, Server Object

Conclusions. ASP.Net has many objects and is easy to use. Therefore, ASP.NET can be one of the recommendations for use in creating Web libraries
\end{abstract}

Keywords: Library applications, ASP.Net, library technology

\begin{abstract}
ABSTRAK
Pendahuluan. Saat ini kita memasuki era dimana penggunaan teknologi dalam kehidupan sehari-hari sangatlah wajar. Penggunaan teknologi ini ternyata menjadi tantangan tersendiri bagi penyedia informasi, salah satunya perpustakaan. Perpustakaan harus mampu menyajikan informasi yang berkolaborasi dengan teknologi agar informasi dapat tersampaikan secara efektif dan efisien kepada penggunanya. Salah satunya dengan menyediakan website perpustakaan menggunakan ASP.Net, yaitu teknologi server side untuk mengembangkan aplikasi web berbasis framework Microsoft.NET. Dengan demikian perpustakaan dapat membuat situs dinamis dan aplikasi web yang interaktif, mudah digunakan, mudah dikembangkan.

Metode penelitian. Dalam melakukan pengumpulan data dalam makalah ini penulis menggunakan metode pengumpulan data berupa kajian literatur

Hasil dan Pembahasan. Artikel ini membahas mengenai sejarah ASP. Net dan Objek-objeknya yakni Namespace, Web Form, Sintaks Dasar Web Form, Class Page, Objek Request, Objek Respone, Objek Server

Kesimpulan dan Saran. ASP.Net memiliki banyak objek dan kemudahan dalam penggunaannya. Oleh karena itu, ASP.NET bisa menjadi salah satu rekomendasi untuk digunakan dalam membuat Web perpustakaan,
\end{abstract}

Kata Kunci: Aplikasi Perpustakaan, ASP.Net, Teknologi Perpustakaan 


\section{A. PENDAHULUAN}

Perpustakaan merupakan salah satu lembaga penyedia informasi selain Kearsipan dan Museum. Namun, dibandingkan dengan Kearsipan dan Museum, pengguna jasa informasi perpustakaan lebih banyak dan beragam. Hal ini dikarenakan perpustakaan memang bersifat terbuka akan informasi yang dimilikinya dibandingkan dengan museum atau keasipan yang memang memiliki peraturan khusus akan informasi yang dimilikinya karena ada yang mengandung rahasia yang menyangkut penyelenggaraan kepemerintahan dan kebangsaan.

Dalam mempersipakan layanan terbaiknya, perpustakaan harus mempertimbangkan segala sesuatunya agar dapat memberikan layanan prima kepada pemustaka. Salah satunya dalam pengembangan Teknologi Infomasi yang dimilikinya. Teknologi Informasi adalah ilmu pengetahuan dalam bidang informasi berbasis computer dan perkembangannya sangat pesat. ${ }^{1}$ hal pemilihan aplikasi software yang tepat untuk menjalankan sistem database yang dimilikinya. Adapun salah satu pengembangan platform saat ini adalah dengan menggunakan ASP.NET yang merupakan teknologi server-side untuk mengembangkan aplikasi web berbasis Microsoft .NET framework. ${ }^{2}$ Penggunaan ASP.NET ini mungkin tidak sebanyak penggunaan PHP dan MYSQL yang digunakan pada Facebook, dan Wordpress. Namun, ASP.NET ini dapat digunakan dalam pembuatan situs yang dinamis dan aplikasi web yang interaktif yang tidak kalah dengan PHP dan MYSQL.

Berdasarkan latar belakang diatas, maka penulis merasa perlu mengangkat topik mengenai ASP.NET ini didalam makalah ini, sehingga dapat menambah wawasan apasaja kelebihan dan komponen yang ada pada ASP.NET ini.

\footnotetext{
${ }^{1}$ Lantip Diat Prasojo, dan Riyanto, Teknologi Informasi Pendidika ( Yogyakarta: Gava Media, 2011), 4.

${ }^{2}$ Iid Anwar Hidayat, Modul Praktikum: Pemrograman Web Menggunakan ASP.NET(Cirebon: LABKOM STIKOM Poltek Cirebon, 2015), 4.
} 


\section{B. METODE PENELITIAN}

Dalam melakukan pengumpulan data dalam makalah ini penulis menggunakan metode pengumpulan data berupa kajian literatur. Pengertian kajian literatur menurut Kumar, adalah, "research study is to go through the existing literature in order to acquaint yourself with the available body of knowledge in your area of interest". ${ }^{3}$ Berdasarkan pernyataan tersebut dapat diketahui jika kajian literatur merupakan kajian yang didasarkan dengan cara merujuk pada berbagai literatur yang sesuai dan diminati oleh penulis. Berbagai sumber rujukan ini menurut Kumar dapat diperoleh melalui tiga sumber, yaitu melalui buku, jurnal ataupun internet. ${ }^{4}$

\section{HASIL DAN PEMBAHASAN}

\section{Sejarah dan Gambaran ASP.NET}

Active Server Pages (ASP) merupakan teknologi dibawah naungan Microsoft yang diperkenalkan pada tahun 1996. Sebalum ada ASP, terlebih dahulu platform Mocrosoft mengembangkan CGI dan ISAPI yang mana juga dapat digunakan dalam membuat website aktif. Kemudian, kedua platform tersebut dikembangkan menjadi ASP yang dapat memudahkan dalam mengeksekusi baris kode ke dalam halaman web. Meskipun pada saat itu ASP merupakan teknologi baru namun ASP mampu menjadi bagian terpenting dalam pembuatan website dinamis. Pada tahun 1998 Microsoft memperkenalkan ASP 2.0 sebagai bahan dari Windows NT 4.0. Pada tahun 2000 ASP 3.0 muncul untuk menggantikan ASP 2.0 meskipun keduanya pada saat itu tidak terlalu signifikan perbedaanya. Kemudian, pada tahun yang sama, yaitu bulan Juli tahun 2000 Microsoft kembali meluncurkan .NET sebagai pembaharuan dari ASP 3.0. ${ }^{5}$ Munculnya frame work .NET dari Microsoft ini semakin mempermudah programmer dalam membuat program yang lebih ringkas dan cepat. Hal ini dikarenakan penggunaan framework pada .NET yang dapat mengurangi jumlah script yang dibuat ole programmer. ${ }^{6}$

\footnotetext{
${ }^{3}$ Ranjit Kumar, Research Methodology: a step-by-step guide for beginners, - $3^{\text {rd }}$. Ed., (London: SAGE Publications Ltd, 2011), hlm. 46.

${ }^{4}$ Ibid., hlm. 48.

5 Universitas Gunadarma, "Modul ASPdotNET", dalam www://asani75.web.id/wp/content/uploads/2015/03/Modul-ASPdotNET-2015.pdf (diakses 2 Juni 2016)

${ }^{6}$ Ari Fadli, Dasar-Dasar ASP, http://nyoman,dosen.narotama.ac.id (diakses pada 2 Juni2016)
} 
Seperti yang kita ketahui, ASP.NET merupakan teknologi server-side yang mengembangkan aplikasi web berbasis Microsoft .NET framework. ASP.NET dapat meminterpretasikan file-file yang dikirimkan pada sever web, sehingga kode halaman dapat dibaca oleh server untuk menghasilkan HTML, JavaScript dan CCS (Cascading Style Sheet) yang kemudian dikirim ke browser. Dalam menjalankan ASP.NET ini diperlukan adanya web server IIS (Internet Information Service). IIS merupakan web server dari Microsoft Windows. ${ }^{7}$ Adapun kelebihan dari ASP.Net antara lain sebagai berikut: ${ }^{8}$

1) Kemudahan dalam mengakses berbagai layanan library .NET framework secara konsisten dan powerfull yang mempercepat pengembangan aplikasi.

2) Penggunaan berbagai bahasa pemrograman secar penuh seperti VB.NET, C\#, J\#, dan $\mathrm{C}++$ yang dapat bekerja secara penuh sebagaimana layaknya Windows Application.

3) Tersedianya berbagai Web Control yang dapat digunakan dalam membangun aplikasi secara cepat .

Dalam ASP.NET ini memiliki dua bagian utama, yaitu bagian Common Language Runtime (CLR) dan .NET Framework Class library (FCL). Adapun penjelasan dari kedua bagian tersebut antara lain sebagai berikut: ${ }^{9}$

\section{Common Language Runtime (CLR)}

CLR berfungsi mengatur memori, mengatur thread, menjalankan kode verifikasi keamanan kode, kompilasi, dan sistem service yang lain.

\section{2. .NET Framework Class library (FCL)}

FCL berisi koleksi class yang dalam penggunaannya dapat diturunkan menjadi kode class menjadi objek yang dapat digunakan untuk membangun aplikasi.

Kedua bagian utama diatas digunakan sebagai Scalability dan Availability yang dapat mengatur variable session melewati server web yang kompleks dalam suatu server. Adapun manfaat dari ASP.NET ini antara lain sebagai berikut: ${ }^{10}$

\footnotetext{
${ }^{7}$ Iid Anwar Hidayat, Modul Praktikum: Pemrograman

${ }^{8}$ M. Choirul Amri, "Pengantar ASP", dalam http://www.choirulamri.ac.id (diakses 3 Juni 2016)

${ }^{9}$ Universitas Gunadarma, "Modul ASPdotNET".

10 Ibid.
} 
1. Mempermudah pengembangan, karena menyediakan model objek yang sangat banyak yang dapat digunakan oleh para pengembang.

2. Kebebasan Bahasa, yaitu adanya flesibelitas dari ASP.NET yang dapat disusun dengan berbagai bahasa karena menyediakan kompatibilitas antar bahasa.

3. Mempermudah Penyebaran, yaitu adanya kemudahan dalam pemasangan komponen ke lokasi yang sudah digambarkan.

4. Kemampuan Cross-Client, yaitu tersedianya komponen server yang kaya yang secara otomatis membuat keluaran yang spesifik yang telah ditentukan berdasarkan tiap tipe clientnya.

5. Web Service, yaitu adanya fitur yang mengijinkan para pengembang membuat web service yang mengalami kesulitan dan mengerti HTTP, dan HTML.

6. Daya Guna, yaitu adanya penyimpanan kedalam memori oleh CLR yang menyimpan setiap terjemahan halaman yang dapat digunakan dalam kegiatan selanjutnya.

Adapun perbandingan ASP dengan PHP secara umum adalah sebagai berikut: ${ }^{11}$

Tabel 1. Perbedaan ASP.Net dengan PHP

\begin{tabular}{|c|c|c|c|c|}
\hline No & Unsur Pembanding & \multicolumn{2}{|l|}{ ASP } & PHP \\
\hline 1 & Sistem Operasi & \multicolumn{2}{|c|}{ Microsoft Windows } & Unix, Linux \\
\hline \multirow[t]{3}{*}{2} & Web Server & $\begin{array}{l}\text { Personal } \\
\text { (PWS) }\end{array}$ & Web Ser & Apache Web Server \\
\hline & & \multicolumn{3}{|c|}{ Internet Information } \\
\hline & & \multicolumn{3}{|c|}{ Server (IIS) } \\
\hline 3 & Database & \multicolumn{2}{|c|}{$\begin{array}{l}\text { Microsoft Access } \\
\text { Microsoft SQL Server }\end{array}$} & $\begin{array}{l}\text { MYSQL,Postgres, } \\
\text { Oracle, dll }\end{array}$ \\
\hline 4 & Basic Sintaks & \multicolumn{2}{|c|}{ Visual Basic (VB) } & $\mathrm{C} / \mathrm{C}^{++}$ \\
\hline 5 & Ekstensi File & \multicolumn{2}{|l|}{.asp } & .php \\
\hline
\end{tabular}

${ }^{11}$ Lisetyo, "Materi Pertemuan ke 9", dalam http://lisetyo.staff.gunadarma.ac.id (diakses 3 Juni 2016) 


\section{Objek-Objek Dalam ASP.NET}

ASP.NET merupakan platform yang terkenal karena memiliki banya objek-objek didalamnya, adapun objek-objek tersebut adalah sebagai berikut:

\section{1) Namespace}

Namespace merupakan suatu skema penanaman logic untuk mengelompokkan tipe-tipe yang saling berkaitan. Hal ini menunjukkan jika objek yang ada pada ASP.NET telah dikelompokkan berdasarkan tipe-tipenya. Namespace terdiri dari susuna induk atau root, dimana Namespace system merupakan root untuk seluruh .NET Framework yang didalamnya terdapat class-class yang mendefinisikan event-event, interface-interface, atribut-atribut, dan pemrosesan exception. Adapun daftar Namespace system ini adalah sebagai berikut: ${ }^{12}$

a. System.CodeDom: berisi objek-objek yang menggambarkan kode0kode sumber dokumen.

b. System.Collections: berisi objek, seperti list, queque, dan hast table.

c. system.ComponetModel: berisi objek yang bisa menjalankan komponen dan control.

d. System.Configuration: berisi objek dan method untuk mengakses konfigurasi

e. System.Data: Berisi class-class yang dapat melakukan interaksi dengan sumber data.

f. System.Diagnostics: berisi class-class untuk melakukan debugging aplikasi.

g. System.Directory Services: berisi akses ke layanan Active Directory.

h. System.Drawing: berisi class-class untuk mrnggunakan kemampuan Gaphical Display Interface (GDI).

i. System.Enterprise Service: berisi objek untuk mengontrol perilaku komponen server.

j. System.Globalization: berisi class yang mengidentifikasi informasi yang berkaitan dengan kultur.

k. System.IO: berisi class-class yang dugunakan dalam membaca dan menulis data stream dan file.

1. System.Management: berisi class untuk berinteraksi dengan event WMI(Windows Management Instrumentation).

m. System.Messaging: berisi class untuk bekerja dengan message melalui jaringan.

${ }^{12}$ Didik Dwi Prasetyo, Aplikasi Web Mobile Menggunakan ASP.NET (Jakarta: PT Elex Media Komputindo, 2005), 39 
n. System.Net: berisi class untuk bekerja dengan protocol jaringan.

o. System.Reflection: berisi class dan interface yang menyediakan method dan field secara dinamis.

p. System.Resources: berisi class dan interface yang bisa membuat, menyimpan, dan mengelola sumberdaya aplikasi.

q. System.Security: berisi struktur dasar sistem keamanan .NET Framework.

r. System.Security berisi struktur sistem keamanan NET Framework dasar untuk izin hak akses.

s. System.ServiceProcess: berisi class untuk mengontrol aplikasi service.

t. System.Text: berisi class yang mepresentasikan karakter ASCII, UTF-7, UTF-8, dan Unicode

u. System.Threading: berisi class dan interface untuk membuat pemrograman mutu threading.

v. System.Timer: berisi komponen timer untuk mengatur interval event.

w. System.Web: berisi class dan interface komunikasi untuk server-browser.

x. System.XML: berisi class untuk memproses dara XML.

\section{2) Web Form}

ASP.NET Web Form merupakan model pemrograman CLR yang scalable, sehingga dapat menghasilkan halaman web yang dinamis. Pada halaman Web Form terbagi menjadi dua bagian, yaitu komponen visual dan komponen logic. Pada komponen visual terdiri atas HTML, kontrol-kontrol server ASP.NET, atau keduanya. Adapun komponen Logic berisi kode-kode yang kita ciptakan untuk berinteraksi dengan form. ${ }^{13}$

\section{3) Sintaks Dasar Web Form}

1. Sintaks Directive, berfungsi untuk mengontrol halaman dikompilasikan, mengatur ketika navigasi antar halaman, membantu proses debugging, dan memungkinkan mengimpor class-class pada halaman. Adapun atribut dalam jenis ini adalah page, control, import, implements, register, assembly, outputcache, dan reference. ${ }^{14}$

\footnotetext{
${ }^{13}$ Ibid., 43

${ }^{14}$ Ibid., 44
} 
2. Blok Deklarasi Code, berfungsi untuk mendefinisikan variael-variabel member serta method yang dikompilasikan dan merepresentasikan halaman ASP.NET. adapun penulisannya nmenggunakan VB, dan C\#. ${ }^{15}$

3. Blok Kode Render berfungsi sebagai kompatibilitas sintaks dengan halaman ASP yang sudah ada. Kode ini bertugas mendefinisikan kode inline atau ekspresi inline yang dijalankan ketika halaman dikembalikan. ${ }^{16}$

4. Sintaks Control Server Custom, kontrol-kontrol dari control server yang ditulis oleh user dengan menggunakan directive register dengan menyertakan attribute TagPrefix dan Runat. $^{17}$

5. Sintaks Objek Server-Side, berfungsi untuk mendeklarasikan dan menciptakan objekobjek COM dan .NET didalam halaman Web Form.

4) Class Page

Class page merupakan representasi dari sebuah file .aspx, yang akan dikompilasi sebagai objek page pada saat runtime dan di chace kedalam memori sistem. Dalam class Page terdapat property public seperti Application. IsPostBack, IsValid, Request, Response, Server, dan Session. ${ }^{18}$

\section{5) Objek Request}

Objek Request berfungsi menyediakan akses ke halaman-halaman yang melakukan request, meliputi request harder, cookies, string query, dan sebagainya. Adapun property yang dimilki pada request ini adalah ApplicationPath yang berguna untuk mendapatkan path root aplikasi ASP.NET; Browser untuk mendapatkan informasi mengenai kemampuan browser yang digunakan melakukan request; Cookies untuk mendapkan kumpulan cookie yang dikirim oleh client; PhysichalApplicationPath untuk mendapatkan file system fisik dari eksekusi aplikasi. ${ }^{19}$

6) Objek Respone

Memiliki property seperti Buffer, untuk mendapatkan atau mengatur nilai proses output di buffer; ContentType untuk mendapatkan tipe WIME HTTP dari outputstream; dan Status untuk menatur baris status yang akan dikembalikan kepada client. $^{20}$

\footnotetext{
15 Ibid., 46

16 Ibid., 47

17 Ibid., 48

18 Ibid., 53

19 Ibid., 54

${ }^{20}$ Ibd., 56
} 
7) Objek Server

Objek Server berguna untuk menyediakan method-method yang dapat digunkan untuk mengirim control antar halaman, medapatkan informasi mengani kesalahan terbaru, encode, dan decode teks HTML, setra beberapa method lainnya. ${ }^{21}$

\section{PENUTUP}

Dewasa ini perkembangan aplikasi software sangatlah banyak dan menawarkan fitur yang beragam, termasuk ASP.NET. Pada ASP.Net memiliki banyak objek dan kemudahan dalam penggunaannya. Oleh karena itu, ASP.NET bisa menjadi salah satu rekomendasi untuk digunakan dalam membuat Web perpustakaan, karena memiliki banyak objek yang bisa disesuaikan dengan kebutuhan dan memungkinkan kemudahan dalam pengembangan.

\section{DAFTAR PUSTAKA}

Amri, M. Choirul. "Pengantar ASP", dalam http://www.choirulamri.ac.id, diakses 3 Juni 2016.

Fadli, Ari. Dasar-Dasar ASP. http://nyoman.dosen.narotama.ac.id, diakses pada 2 Juni 2016.

Hidayat, Iid Anwar. Modul Praktikum: Pemrograman Web Menggunakan ASP.NET.

Cirebon: LABKOM STIKOM Poltek Cirebon, 2015.

Kumar, Ranjit. 2011. Research Methodology: a step-by-step guide for beginners, -

3rd. Ed. London: SAGE Publications Ltd.

Lisetyo. "Materi Pertemuan ke 9", dalam http://lisetyo.staff.gunadarma.ac.id, diakses 3 Juni 2016.

Prasetyo, Didik Dwi. Aplikasi Web Mobile Menggunakan ASP.NET. Jakarta: PT Elex Media Komputindo, 2005.

Prasojo, Lantip Diat, dan Riyanto. Teknologi Informasi Pendidika. Yogyakarta: Gava Media, 2011.

Universitas Gunadarma. “Modul ASPdotNET”, dalam www://asani75.web.id/wp/content/uploads/2015/03/Modul-ASPdotNET-2015.pdf, diakses 2 Juni 201

21 Ibid., 57 